\title{
Empire, Resistance, and Security: International Law and the Transformative Occupation of Palestine
}

\section{Introduction}

The Nazi empire's conquest of Europe and mass crimes during World War II intensified the controversial connotations of the geopolitical keywords "occupation," "colonialism," and "imperialism." Empire within Europe was pronounced intolerable. The Atlantic Charter issued by United States president Roosevelt and British prime minister Churchill in 194I declared the Allied determination to restore "sovereign rights and self government" to "those who have been forcibly deprived of them" by the Nazis. ${ }^{1}$ Not for nothing did Raphael Lemkin, the Polish lawyer who coined the term "genocide" in 1944, call his book about the German empire Axis Rule in Occupied Europe. For him, genocide was a "new technique of occupation aimed at winning the peace even though the war itself is lost"; by destroying, disintegrating, and weakening an "enemy nation," the occupier is "in a position to deal with . . o other peoples from the vantage point of biological superiority." 2 In his rendering, such a revolutionary occupation was a modality of colonial domination and imperial rule that also violated the Rousseau-Portalis maxim making warfare a transaction between states rather than populations, combatants rather than civilians. ${ }^{3}$ These views were institutionalized in part when, within five years of the war's end, the International Military Tribunal (the Nuremberg Trials), the United Nations (UN), and the International Committee of the Red Cross (ICRC) proscribed wars of conquest, crimes against humanity, and genocide. ${ }^{4}$

Empire was not banished entirely, however, even within Europe. There would be no self-determination for Lemkin's native Poland after the Soviet occupation, an ugly fact that the Western Allies had to swallow. ${ }^{5}$ Outside Europe, the British, French, and Dutch governments expected to retain or regain their empires, and they designed the UN to help them do so. ${ }^{6}$ If they had been reforming their liberal empires-liberal compared to the Nazis and Soviets—by substituting development for civilizing missions, Western elites did not regard their far-flung possessions as illegitimate; for them, spreading civilization to the natives and safeguarding civilization from Nazi barbarism were one and the same endeavor. ${ }^{7}$

Sensing this enduring imperial commitment, Indian nationalists predicted that the Atlantic Charter would not apply to their country. Accordingly, some of them sided with the Axis powers against the British, already disillusioned by the passing of the "Wilsonian Moment" at the end of World War I. ${ }^{8}$ The Japanese, stung by the failure to secure a racial equality clause in the Treaty of Versailles, issued their own version of 
the Atlantic Charter, the Great East Asian Declaration, to apply to all peoples. ${ }^{9}$ That Japan also engaged in predatory imperialism only served to darken empire's reputation. Expressing the common non-European suspicion of the Western powers and their continuing imperial versions of global order, the Ghanaian independence leader Kwame Nkrumah wrote in 1963 that "they [Allies] proclaimed the Atlantic Charter and the Charter of the United Nations, and then said that all these had no reference to the enslaved world outside the limits of imperialism and racial arrogance." ${ }^{10}$ Much to the chagrin of the Western imperial elites, however, they found the UN's General Assembly less malleable than foreseen; the ensuing decolonization struggles soon led to a new global order populated predominantly by independent nation-states.

Colonial occupations seemed to belong to a bygone age.

For all that, the legal doctrine of belligerent (or military) occupation, a key component of the international humanitarian law (IHL: formerly known as the laws of war) that regulates armed conflict, remained a geopolitical fixture. Beginning with the Hague Conventions of 1899 and 1907, IHL shaped the norms, if not the reality, of occupations of conquered territory by granting the victor specific rights as well as imposing certain obligations. Postwar legal innovations like the Third and Fourth Geneva Conventions of 1949 and the Additional Protocols of 1977 increased protection for occupied civilians and those who resisted occupation but did not banish the centuries-old jurisprudence about warfare and its consequences, in which the killing of civilians can be legally sanctioned by proportionality principles. ${ }^{11}$

At the same time, the rights of conquered people, embodied in the ideal of national liberation and self-determination, have long been asserted against occupation and colonial domination, and became the post-World War II norm, most pointedly in UN General Assembly resolutions in the I960s and 1970s. ${ }^{12}$ The significance of decolonization and human rights jurisprudence since 1948 lies partly in the particular scrutiny to which belligerent occupations are now subject, interpreted, as they often are, as illegitimate colonial projects. ${ }^{13}$ Occupation's multiple meanings are evident in Lemkin's own legal and political-ideological usages of the term: occupation invoked the 1907 Hague Regulation to which he constantly referred, it alluded to the originally Roman doctrine in the law of nations about the acquisition of empty land, and it functioned as a metaphor for, and mode of commencing, colonial rule and imperial expansion. ${ }^{14}$

Given that belligerent occupation is regarded as legally valid but politically suspect, states have been reluctant to embrace the term for their occupation regimes-for instance, the American-led invasion and occupation of Iraq in 2003. For its ambitious program of institutional reform that echoed various UN peace-keeping and -building missions from the I990s, the Oxford scholar Adam Roberts used the term "transformative occupations." 15 Because such occupations are intended as temporary trusteeships to benefit the occupied, the transformative occupations literature distinguishes them from belligerent occupations and thus ignores the fraught Israel/Palestine case. ${ }^{16}$ Indeed, here the demographic and infrastructural transformation benefits the occupier: the colonization of the West Bank by over half a million settlers, the insertion of buildings, roads, checkpoints, and now a putative security wall running extensively beyond the Green Line that sunders Palestinian urban neighborhoods and 
villages, even separating them from their farmland. ${ }^{17}$ This supposedly temporary occupation resembles a permanent annexation of "Biblical lands" — as settler leaders and Israeli politicians routinely proclaim. ${ }^{18}$

Of all occupation regimes since World War II, this one has been among the most dramatically transformative, irrespective of the beneficiaries. Whereas the transformative occupations literature tends to locate the notion's origins in the French revolutionary wars of liberation, followed by international practices of trusteeship and mandated territories that supposedly benefit the occupied, the account given here complicates the tidy distinction between occupation regimes. It shows how occupations, broadly defined, often entailed settlement by occupants and the economic transformation of the acquired territory to their advantage. Consequently, colonial and imperial history is an intrinsic part of the story. ${ }^{19}$ The question thus presses itself upon us: does IHL inhibit or enable a transformative occupation that is indistinguishable from colonial rule?20

The Israel/Palestine case provides the material for an answer. What if no treaty is signed and the occupation becomes a "prolonged military occupation," as Adam Roberts puts it?21 Already in 1973 - soon after the Israeli conquest of the Gaza Strip and West Bank in 1967-one scholar recognized that "traditional principles of international law" did not help "Israeli policy planners formulate rational and equitable solutions," inferring that Israel should act as a "trustee-occupant" to foster "independent economic and political development" aimed, ultimately, at West Bank Palestinian self-determination. ${ }^{22}$ This aspiration seemed like a vain hope only a few years later as the colonization of the territory with settlers and their infrastructure proceeded apace. ${ }^{23}$ Counseling caution, Roberts advises that IHL can at most mitigate the Israeli occupation, and that all sides should place their faith in an eventual political settlement. ${ }^{24}$ That was the best for which Palestinians could hope from the law, he suggested, while the West Bank in particular was being transformed by its prolonged occupation. For many Palestinians, entreating patience and faith in political processes was, and remains, a counsel of despair.

For their part, Palestinians and their advocates have invoked international law to assail Israeli policies and practice since the I950s, when Israeli raids on Jordanian villages, in reprisal for cross-border attacks by Palestinian guerrillas, caused high civilian casualties. Arguments about (dis)proportionality were also advanced after the so-called Second Lebanon War in 2006, as they were in relation to the Israeli airstrikes, shelling, and motor attacks on Gazan targets in 2008/9 and 20I4. Commentators leveled accusations of war crimes, in particular due to assaults on UN buildings that killed sheltering civilians. ${ }^{25}$ Since 1967 , these advocates have maintained that Israeli settlement of the West Bank violates the Geneva Conventions. Sometimes, they insist on the legal "right of return" for Palestinian refugees, supposedly vouchsafed by a UN General Assembly resolution (No. 194 of December II, 1948), to reverse the transformation of their homeland and to realize Palestinian self-determination. These advocates appeal to international law as a seemingly neutral arbiter to mitigate, perhaps even to end "the occupation." All would be well, they imply, if Israel complied with international law. ${ }^{26}$

There are reasons for skepticism about this hope when security concerns, however 
specious, can justify virtually all of Israel's actions. The time has come to question the presentist perspective that places such faith in IHL and instead consider the proposition that it facilitates rather than prevents this transformative occupation. A historical analysis of the recurring arguments used in the international system reveals that the Israeli arguments are not novel; security and self-defense imperatives have authorized Western conquest and occupation for half a millennium. Little prevents an occupation from becoming a transformative colonial annexation, because IHL-as opposed to nonbinding UN General Assembly resolutions about self-determinationplaces strict limits on the ability of indigenous peoples to assert their national liberation, while its provisions inhibit occupiers from transforming the land and its demography far less than commonly supposed. ${ }^{27}$ IHL is anything but a neutral court of appeal for indigenous people.

In this essay, I identify and examine the legal-rhetorical mode of reasoning that justifies colonial-transformative occupations by legitimizing the repression of indigenous resistance via appeals to self-defense. This reasoning unites the otherwise disparate meanings of the occupation keyword: as the acquisition of title to vacant or unused land, the legal regulation of military holding of captured territory during peace negotiations, and as a metaphor for colonialism. In the first case, one-off reprisals or counterinsurgencies can lead to long-term, indeed permanent occupations by this reasoning's political-legal logic of exacerbation, in which the initial foreign presence is consolidated and expanded to secure its existence in the face of indigenous hostility. In the second, the discretionary power authorized by the law of occupation in defense of the occupant's security becomes, in the hands of a prolonged occupying power with territorial ambitions, the door through which an entire cart and horses of colonial apparatus can be driven. ${ }^{28}$ In both cases, the security imperative can justify permanent occupation, that is, colonial rule.

In this way, the mode of reasoning continues what nineteenth-century historians apologetically called the "defensive imperialism" of the Roman Empire, namely, the security exception that authorized the violent extension of the occupier's project. ${ }^{29}$ It is no accident that colonial historians of North America use the term "defensive conquest" to name this modality of settler expansion. ${ }^{30}$ John Seeley's famous observation that the British "seem, as it were, to have conquered half the world in a fit of absence of mind" also captures this consoling sense of conquest by accident rather than by design. ${ }^{31}$

What is more, in otherwise criticizing and normatively constraining colonial violence, this mode of reasoning enables the belief that empire was attained lawfully, whether for Christianity in the early modern period, or later on in the name of civilization. ${ }^{32}$ To be sure, Western critiques of empire since the sixteenth century have not been a fig leaf for empire, just as human rights provisions today often stand in tension with IHL. This tension is real, inducing hesitation and ambivalence as well as dissemblance. At the same time, ambivalence about wanton conquest as opposed to legal colonization constitutes a central element of whiggish commentaries that celebrate IHL for gradually humanizing the conduct of war and occupations. ${ }^{33}$ By overlooking the persistence of the security exception, this optimistic narrative cannot account for enduring colonial rule today. Just as the paradox of a liberal order is its underwriting 
by a sovereign that stands above the law and can declare states of exception, so liberal—read: legal—imperial expansion is undertaken by an alien power that violently imposes and then maintains power in states of emergency. ${ }^{34}$

This essay traces the crystallization and development of this mode of reasoning about empire, indigenous rights, and colonial security in influential and symptomatic authors since the early modern period, arguing that its formation can be located then rather than primarily in the nineteenth century. ${ }^{35}$ In doing so, it does not posit the ontological stability of this mode of reasoning nor ascribe to it transcendent power in time and space-the "idealist mistake of attributing global potency to legal theorists," as Patrick Wolfe put it. ${ }^{36}$ Still less does it presume a "continuous tradition of international thought . . . from early modernity," a belief that one authority calls mythic. ${ }^{37}$ The meaning and traction of particular arguments depends on the immediate uses to which they are put and the broader historical trends they serve.

And yet, the consistent citation of earlier authorities and re-positing of origin stories for legitimacy claims points to an inventory of arguments that thinkers and actors assimilated into their thought as articles of faith, whether religious or secular, or consciously adapted, thereby making for some regularity in its content. ${ }^{38}$ Just as the uses to which arguments are put and trends they serve can be reconstructed, so can their reiterations and developments that conceptualize and justify occupation.

For reasons of economy, the following account is necessarily selective. It highlights only a small number of figures, neither attending closely to the particular circumstances of their adaptations nor engaging in exhaustive discussions of the punctual moments treated in the sections below, still less providing a drafting history of particular codes and conventions. ${ }^{39}$ The intention of this critical intellectual history is rather to lay bare the longue durée of the key arguments with which the Western empires imposed themselves on the rest of the world. In imposing itself on the West Bank today with considerable acquiescence and impunity, Israel's justifications of its settler-colonial transformative occupation invoke the time-honored arguments analyzed here. ${ }^{40}$

\section{"Origins" and Arguments}

In a relatively contemporary origin story, the influential editor of the American Journal of International Law, James Brown Scott, posited the Spanish theologian Francisco de Vitoria (I485-1546) as the founder of "law of nations." ${ }^{41}$ As Vitoria's affirmers and critics today also ascribe to him this status, I begin here as well. On the one hand, he is interpreted as defending indigenous rights against the rapacious Europeans. He recognized Indians' property rights, on the basis of natural law, against advocates of the Christians' right to conquer and plunder the heathens. He is even credited with founding the tradition of humanitarian intervention that became a prevalent discourse in the nineteenth century. ${ }^{42}$ Lemkin regarded him as a humanitarian hero. ${ }^{43}$

On the other hand, as scholars like Antony Anghie have noted, Vitoria also advanced a case that justified European conquest and even terror in virtually humanistic terms that would later lend international law its patina of impartiality and civilization. ${ }^{44}$ This mode of argumentation has been all the more effective for its disarming yet fatal blend of moral advocacy together with a presentation of violence 
as subjectively understood acts of self-defense. ${ }^{45}$ The "law of nations" (or "peoples": jus gentium) avowed universal friendship and sociability, and therefore the right of the Spanish to engage in exploration, commerce, and resource extraction in Indian lands. Consequently, the Indian prevention of the Spanish from engaging in such activities, especially if other foreigners were doing so, constituted "acts of war." ${ }^{46}$ Spanish retaliation was therefore "permissible self-protection," wrote Vitoria, against the Indians' attempted "destruction" of the Spanish, who could now treat them as "forsworn enemies, and may enforce against them all the rights of war, despoiling them of their goods, reducing them to captivity, deposing their former lords and setting up new ones." ${ }^{47}$ The central legitimating device here is the proposition that the Spanish would be pushed into defensive measures by the Indians, which depends on the unquestioned assumption of the Spanish right to interact on their terms with indigenous populations. As we will see, this presumed right became central to the link among occupation, colonization, and violence in subsequent European thought.

This presumption was also a function of the distinction made between the moderation of Christian Europeans on the one hand, and the limitless violence of both European antiquity and contemporary savages on the other. Repeatedly, Vitoria condemned the outright extermination of belligerents, an ancient practice said to characterize the Indians. Appealing to Aquinas's just war theory, he maintained that violence was justified only if defensive: to right a wrong and to prevent its repetition. Just as important, however, he repeatedly adumbrated the exceptions, when violence was effectively and legitimately limitless: in circumstances of security and selfpreservation. Although he denied that it was generally permissible to "slaughter the innocent" members of the enemy, he also wrote that the "Prince can do whatever is necessary in order to obtain peace and security from the enemy; for example, destroy an enemy's fortress and even build one on enemy soil, if this be necessary in order to avert a dangerous attack of the enemy." 48 Necessity knew no limitations after all.

Contemporary intellectual historians contrast the scholastic Vitoria's theological appeal to Christian authorities with humanist theorists who drew on classical writers and glorified warfare in the service of the republic. ${ }^{49}$ This distinction can be exaggerated when we consider Vitoria's retention of self-preservation as a natural right. ${ }^{50}$ The leap from Vitoria to the Gentili, Grotius, Pufendorf, Wolff, and Vattel was not so far in this respect, despite the latters' secularization of the law of nations after the fracturing of Christendom. Whether based on natural law and theology or on a distinct, amoral political sphere, the characteristic injunction was-and remains-to restrict killing but then to license the virtually limitless application of violence in circumstances of extreme emergency.

Even by the eighteenth century, thinkers had begun to reflect on popular participation in hostilities. Like Vitoria, they distinguished between the guilty (soldiers) and the innocent (civilians) but also confronted the social nature of warfare and the associated question of collective punishment. In his The Law of Nations, the Swiss diplomat and thinker Emer de Vattel (I7I4-67) attempted to limit war's cruelty by confining its legitimate participation to soldiers acting under orders. Involving populations in military action was a reversion to the barbarous past: "it could scarcely terminate otherwise than by the complete destruction of one of the parties, as the wars 
of ancient times only too well prove," he warned. ${ }^{51}$ At the same time, he understood that it was unrealistic to expect civilians not to spontaneously defend their territory, although they could then be legitimately treated as bandits and summarily executed by the invading army. Vattel was admirably candid in what that suppression entailed, namely, terror. ${ }^{52}$ And by "the enemy," he meant the entirety of the foreign citizenry, because war was founded on the principles of collective membership: "from the moment a Nation takes up arms against another, it declares itself the enemy of all the individual citizens of the latter and justifies them in treating it in turn as such." 53

The ambivalence about indigenous people was evident in Vattel as well. As a Protestant thinker, he did not support the Spanish crown's claims to the Americas: "When the Spaniards attacked the Americans, under a pretense that those people refused to traffic with them, they only endeavoured to throw a colounable [sic] veil over their own insatiable avarice. ${ }^{54}$ Accordingly, the Americans had a right to resist, as he stated in colorful language. In view of the "iniquitous and cruel conditions" of the Spanish rule and exactions, "will any man pretend to assert that he would not have been justifiable in seizing a convenient opportunity to recover his rights, to emancipate his people, and to expel or exterminate the Spanish horde of greedy, insolent, and cruel usurpers? No!" 55 And yet, by evacuating morality from the law of nations, he could not really say that conquest was unjust either; his comments about the Spanish were polemical. It is no coincidence that American revolutionaries took him as their authority for the proposition that the question of their conquest's legitimacy was irrelevant. War was no "longer just or unjust, but regular or irregular." 56

Francis Lieber (I800-1872), the German American jurist and author of influential military codes for the Unionist forces in the American Civil War, followed squarely in Vattel's footsteps in key respects. On the one hand, irregular forces that fought on after their army had surrendered were criminals and could be treated accordingly, for they brutalized warfare. ${ }^{57}$ In the age of the levée en masse, on the other hand, he also knew that a popular rising could not be excluded by fiat. So he held that civilian rebels could be treated as soldiers rather than "war rebels" if they resisted in sufficient numbers and openly opposed the enemy like regular soldiers; they could not fight concealed as civilians: legitimate guerrilla warfare was inconceivable. ${ }^{58}$ Like Vattel before him, Lieber distinguished between the moral right of resistance and the legal right to repress it. In effect, for indigenous peoples and occupied Europeans, then, to resist occupation legitimately (and thereby enjoy the legal protection), they had to do so in circumstances that made their decimation inevitable - and that presumed they disposed over the resources to produce uniforms. ${ }^{59}$

Accordingly, the United States army fought two wars at the time; one, consistent with the Lieber Code, to defeat the Confederacy, and another, without the Code and with exterminationist dimensions, against the Apache and Plains Indians more generally. Consequently, when seven hundred federal militia at Sand Creek, Colorado, massacred up to two hundred members - mostly women and children-of the Cheyenne and Arapaho tribes in 1864, the Code was not invoked in the subsequent investigation and no one was prosecuted ${ }^{60}$ At the end of the century, such warfare would be waged against those resisting U.S. occupation of the Philippines, although this time according to the Lieber stipulations. Because they were categorized as 
insurgent irregulars, they could be summarily executed. In a telling linkage, President Roosevelt denounced these Filipinos as treacherous as "our Arizona Apache." 61 Whether the code was invoked or not made little difference to indigenous people resisting occupation.

Lieber was no lone figure, a maverick of his time. Two years after his Code, Lieber's friend and colleague, the lawyer and Unionist general Henry Wager Halleck (I815-72), drew upon his American Civil War experience to consider the doctrine of "retaliation." Like other writers, he declared that a state can temporarily violate the laws of nations to compel an adversary to cease a course of action that itself violates the laws of nations. Because of its temporary and targeted nature, retaliation was a measure short of war. Noteworthy in Halleck's rendering is the characteristic Western self-understanding of its violence as defensive and civilized in contrast to its opponents' aggressive and uncivilized violence. ${ }^{62}$ The civilized would rise above the savages by adhering to the principles of proportionality as Vitoria had taught. Halleck quoted Lieber's Instructions for the Government of the Armies of the United States in the Field for the proposition that "unjust or inconsiderate retaliation removes the belligerents farther and farther from the mitigating rules of regular warfare, and by rapid steps leads them nearer to the internecine wars of savages." ${ }^{33}$ Civilized warfare was limited.

Again, though, as with Vitoria and subsequent thinkers, there were exceptions to this mitigating principle of sparing the innocent: namely, the rule of collective responsibility and collective punishment. Thus Halleck held that "a city, an army, or an entire community, is sometimes punished for the illegal acts of its rulers or individual members," a conclusion he drew after observing popular support in the Confederacy for extreme measures in the Civil War. "The entire rebel press advocated and justified them, and even the rebel women have so far forgotten their sex and their mission of mercy on earth, as to approve and encourage acts of cruelty which it was supposed could be committed only by a savage people in the most barbarous age." ${ }^{44}$ As before, even in such circumstances, Halleck continued, civilized retaliation "must never degenerate into savage or barbarous cruelty"; it was to stop the evil, not to exact revenge. ${ }^{65}$ This restraint was held to distinguish the West from its others.

Whether such self-justifications bore much relation to the reality of colonial warfare is a question that can be answered empirically. We know that indigenous people experienced Western retaliation as savage and cruel, as the facts of countless counterinsurgency campaigns testify. For instance, as foreshadowed above, tens of thousands of Filipinos died of starvation and disease in the U.S. counterinsurgency operation in Batanguas between 1899 and 1902 when its forces laid waste to the countryside and forcibly separated the population into loyal and disloyal camps. Many other examples could be adduced. ${ }^{66}$

Such tactics were so common because of the consensus that the laws of war did not apply to "savages" in any case. The German historian Heinrich von Treitschke expressed this view when he wrote that "it is a mere mockery . . to apply these principles [of international law] against savages. A negro tribe must be punished by the burning of their villages, for it is the only kind of example which will avail." ${ }^{67}$ Treitschke also reflected a particularly German aversion to irregulars and guerillas, borne of their experiences during occupation of parts of France in the Franco-Prussian 
War of I870-7I when so-called Francs-tireurs (literally, free shooters) tied down German units. They were executed in large numbers. ${ }^{68}$ Outside Europe, the British had long learned this lesson and applied it in their many colonial wars. ${ }^{69}$

The application of international law to non-Europeans also encompassed the acquisition of land. Writing just before The Hague Convention of 1907, Lassa Oppenheim (1858-1919), the German jurist who taught in England in the latter part of his career, defined occupation as a legal category of war for the signatories to the Hague Conventions as well as a synonym for colonization. ${ }^{70}$ Land not under a sovereign was free to be occupied by another power. Occupation was therefore not "subjugation" (by which he meant conquest and annexation) but closely related to "cessions," that is, land taken "from a native tribe living on the land." Because international law related to interstate intercourse, it did not apply to "native tribes."

Consequently, occupations and cessions were effectively the same for Oppenheim and his contemporaries; native chiefs were not sovereigns in a Western sense, nor were they peoples that could claim sovereignty: they were "tribal communities" rather than members of the "family of nations." in the status of the West Bank occupation decades later.

\section{Codifying War}

The European and some non-European powers sought to re-regulate warfare after the Franco-Prussian War. At meetings in Brussels in I874 and then in The Hague in I899 and 1907, the Lieber Code provided a basis for discussion due to its inspiration for the Swiss scholar Johan Casper Bluntschli, who translated it into German, and for F. F. Martens, the Russian diplomat and lawyer who attended his lectures and who played a formative role at the Brussels and first Hague meetings. ${ }^{72}$ Relevant for our discussion was the controversy about defining and treating irregulars or partisans. Some smaller states sought to protect nonmilitary personnel who resisted foreign invasion from summary execution, while larger states viewed partisan or guerrilla warfare as threats to civilized warfare and orderly occupation. The ensuing compromise followed Lieber: Article I recognized civilian resistance so long as "militia and volunteer corps" fulfilled a number of conditions, namely, being subject to a responsible commander, wearing a visible emblem to distinguish them from civilians, carrying arms openly, and conducting "their operations in accordance with the laws and customs of war." Article II also applied the latter two conditions to "inhabitants of a territory which has not been occupied, who, on the approach of the enemy, spontaneously take up arms to resist the invading troops without having had time to organize themselves in accordance with Article I," but ended this application once an occupation was in place. Resisters of a successful conquest were not protected and could be summarily executed as criminals. ${ }^{73}$

These two Hague Conventions did at least place some restrictions on occupiers and proscribed outright conquest: to that extent, they softened Lieber. The 1899 convention also contained the celebrated preamble portion suggested by the Martens to break an impasse between small and large nations about the status of civilian resistance to invasion and occupation. The "Martens Clause," as it has become known, held "that in cases not included in the Regulations adopted by them, populations and 
belligerents remain under the protection and empire of the principles of international law, as they result from the usages established between civilized nations, from the laws of humanity and the requirements of the public conscience." 74 Although vague and interpretable in different ways, it too was a gesture to the rights of occupied peoples.

Whatever the gain in humanizing warfare in Europe, the distinction between civilized and savage warfare continued as before. John Westlake (I828-1913), the prominent English legal theorist, said as much in his book International Law in 1907:

But often the inroads or other outrages committed by savages or half-civilised tribes can only be repressed by punitive expeditions, in which the whole population must suffer for want of a government sufficiently marked off from it. All civilised states which are in contact with the outer world are, to their great regret, familiar with such expeditions in their frontier wars, and the principle that to weaken the military forces of the enemy is the only legitimate mode of action can have no application to them. ${ }^{75}$

He did add that "no humane officer will burn a village if he has any means of striking a sufficient blow that will be felt only by the fighting men" but also did not question why the "savages" were indignant in the first place. Westlake's concern was that Article 25 of the Hague Convention, which prohibits the "attack or bombardment of towns, villages, habitations or buildings which are not defended," did not apply in colonial cases because "the Hague code deals only with war between civilised states." ${ }^{6}$ Perpetrating terror against uncivilized people was legal and just; colonial warfare could continue as before. To this extent, the British and American reservations about the Prussian-German insistence that the exigencies of war trumped every moral consideration-Kriegsraison geht vor Kriegsmanier-appeared rather weak. If the German military grandees did not recognize the doctrine of proportionality, they were merely highlighting the centrality of military necessity that their Anglo-Saxon counterparts applied in their colonial campaigns. ${ }^{77}$

The latter victors in World War I also thwarted colonized people's selfdetermination aspirations at Versailles and consolidated their colonial empires while dismembering Germany's. They persisted in dividing the world into civilized and uncivilized components in which the laws of war applied discrepantly. The British, in the pacification of their mandate in Iraq — not even a colony-had recourse to aerial bombardment of Arab villages, and they had earlier bombed Afghan civilians in I9I5 and 1919, and Italians and French before them in North Africa. ${ }^{78}$ This sort of language persisted into the interwar period as a British wing commander bore out when he averred in 1928 that "of all our mechanical improvements, and our new armoury of weapons, none has given us anything like so great an advantage, and none is so admirably suited to warfare against wild men and in wild countries, as the aircraft." 79

The proximity of the Anglophone and German prohibitions on guerilla resistance to occupation became apparent during World War II. While Anglophone writers recognized the legitimacy of partisan resistance to Nazi occupation in Eastern Europe- "it is perfectly justifiable for them to do so" if they can "carry on really effective guerrilla warfare" - they also observed that partisans could not be "expected to be treated as peaceful non-combatants if they engage in acts of sabotage or war." 
Quoting Halleck, Ellery C. Stowell of Columbia University even defended the collective punishment of civilians:

But when it is not possible to seize those who have committed these acts, it is in accordance with military exigencies, and it has been customary, to impose what are known as repressive reprisals on the whole community where the acts have occurred. As in the case of other military reprisals, this punishes the innocent, but war itself is based upon the principle of collective responsibility. ${ }^{80}$

Nazi criminality, he continued, inhered not in its reprisal killings but in their disproportionality—recall Halleck's advice about not reverting to savagery-thereby piling "hecatomb upon hecatomb of innocent reprisal victims." 11 What the Nazis did, in fact, was to import modalities of colonial warfare into Europe by placing Slavic peoples and of course Jews outside the protection of international law. The point of the infamous "Commissar Decree," issued at the launch of "Operation Babarossa" in I94I, was that IHL did not apply to Soviet soldiers because they were, in Nazi eyes, barbarous in the terms stated by Colby, and because the Soviet Union had not formally signed the Geneva Convention of $1929 .{ }^{82}$ In the paranoia of their governance, the Nazis took the security imperative of self-preservation to its logical, genocidal conclusion.

Even so, the defense of military necessity was widely successful for some Nazi generals at the Nuremberg Trials. In the Hostages case, the International Military Tribunal, following the Hague Regulations of 1907 , held that "military necessity permits a belligerent ... to apply any amount and kind of force to compel the complete submission of the enemy with the least possible expenditure of time, life, and money." 83 Thus, General von Leeb's siege of Leningrad, which lasted more than two years and caused hundreds of thousands of civilian deaths, was excused on the grounds of military necessity because starvation was not prohibited by the Hague Regulations. ${ }^{84}$ Likewise, the execution of partisans was widely passed if they did not meet the combatant requirements of the Hague Regulations. The tribunal even permitted the German execution of civilian hostages as reprisals for partisan attacks because customary international law permitted it. Rescuing military necessity as a concept to enable Allied modalities of warfare meant indulging German generals in what today would be regarded as war crimes. ${ }^{85}$

Partly as a consequence of these excesses, international law since World War II has attempted to make its violation in the name of self-preservation an "excuse," in the sense of mitigating circumstance, rather than a "right." In this vein, the Fourth Geneva Convention of 1949 accorded occupied civilians more protection in military situations, prohibiting collective punishments like reprisals, fines, and hostage taking. ${ }^{86}$ In view of Europe's occupation by the Nazis, many more countries pushed for irregular warfare to receive further protection by extending the Hague protection to enduring resistance to occupation. The British, thinking of their restive imperial possessions, objected to the move and indeed attempted to raise the threshold for lawful belligerency. The ensuing compromise extended the Hague threshold of requiring a command structure, the open bearing of arms, and wearing of insignias that would disadvantage any national liberation movement. ${ }^{87}$ 
The most significant political development for occupations has been the counterprinciple of self-determination, the watchword of the national liberation movements. As new states joined the UN, its General Assembly developed a majority that passed resolutions against racism, colonialism (highlighting Israel after 1967), and apartheid (targeting South Africa and Rhodesia). By declaring self-determination and the rights of Palestinian refugees to be a UN priority, this movement attempted to make civil wars or secessionist wars into international concerns, which entailed investing the national liberation movement with formal belligerent status. ${ }^{88}$ In a variety of resolutions, covenants, and declarations in the I960s and 1970s, the General Assembly even went so far as to say that colonial powers were prohibited from taking "forcible action" to prevent self-determination and, further, that peoples under alien domination could use "any means at their disposal" "to restore to themselves that right" of selfdetermination. ${ }^{89}$ For the Non-Aligned Movement, colonial rule was tantamount to permanent aggression that could be legitimately repulsed in forcible self-defense, although freedom fighters should also respect the laws of war and not terrorize civilians..$^{90}$ This indigenous perspective enjoyed considerable success in the I970s, when many liberation movements were accorded observer status at the UN. ${ }^{91}$

This pressure led to attempts to further extend the protection of the Geneva Convention. Two Additional Protocols to the convention were acrimoniously negotiated during the 1970s. Article 43 of the 1977 Protocols expands the definition of legitimate belligerents to effectively include national liberation movements. Article I(4) provided the context: "armed conflicts in which peoples are fighting against colonial domination and alien occupation and against racist régimes in the exercise of their right of self-determination." Article 44(3) confers prisoner of war status on such belligerents. The protocols, as Antonio Cassese put it, meant that national liberation movements could avoid the customary stigmatization "as a bunch of rebels fighting against the established authority"; now they "could claim to be an international subject entitled to exercise rights and duties on the international level." ${ }^{2}$ Here was real progress, it seemed.

\section{The Persistence of the Security Exception}

Notwithstanding these extensions of protection to civilians and even to those resisting occupation, a number of qualifications meant that the latter were as disadvantaged as ever. The centuries-old legal prescription to carry arms openly, and "to distinguish themselves from the civilian population while they are engaged in an attack or in a military operation preparatory to an attack," stood as before. ${ }^{93}$ Article 96(3) requires such movements to declare that they undertake to abide by the Geneva Conventions and Protocols. Article 44(3) is not considered customary international law. ${ }^{94}$

Moreover, the protocols do not define persons who do not meet protected belligerent stipulations, leaving them open to classification as "unlawful combatants" who need not be treated as prisoners of war. ${ }^{95}$

Nonetheless, the protocols were not warmly greeted by the Western alliance, whose members abstained in the deciding vote, while Israel, at which the protocols were aimed, opted out altogether; accordingly, they carry little weight in the Israel/ 
Palestine conflict. ${ }^{96}$ Israel also denies the de jure application of the Geneva Conventions to the occupied territories, although it came to recognize their de facto force after Yoram Dinstein, a law professor at Tel Aviv University and former consul of the government of Israel in New York, argued that they represented customary and not conventional law. ${ }^{97} \mathrm{He}$ also criticized - though to no effect- the Israeli claim of title to the West Bank, because, unlike Gaza and the Golan Heights, Jordan was not its legal occupier after 1948. The state denies that West Bank Palestinians possess the status of a people that can assert self-determination, a view continuing venerable arguments about indigenous people's lack of status in international law. ${ }^{98}$ Dinstein's scrupulous adherence to IHL is significant because he thinks it is consistent with Israeli colonization practices. Its occupation, he declared in 1972, was "benign." 99

In insisting that IHL applies to the occupied Palestinian territories, Dinstein has spelled out in detail how IHL facilitates a prolonged, indeed transformative occupation. Because of Dinstein's prominence as the doyen of Israeli international lawyers and globally recognized expert on the laws of occupation, his views warrant special attention. ${ }^{100}$ They bear out the colonial potential of belligerent occupation in a number of domains by demonstrating how the security exception can trump limitations on the occupant's ability to transform the territory. IHL, he notes, has nothing to do with humanitarianism or even human rights. The rights it confers pertain more to states than to individuals: "Belligerent occupation is not designed to win the hearts and minds of the local inhabitants: it has military—or security—objectives, and its foundation is the 'power of the bayonet.' "101 Despite the common view, no legal right of resistance exists in the Israeli occupation, as the Additional Protocols do not apply to this case. ${ }^{102}$ Even if they did, we will see, they do little to protect Palestinian resistance to occupation.

Acts of sabotage are crimes and the occupant can decide which acts constitute sabotage. "Saboteurs," to use the language of the Fourth Geneva Convention (Article 5), can be interned for reasons of "absolute military security" and "without supervision." The Geneva Convention (Article 64) also permits the suspension or repealing of domestic law where it constitutes "a threat to its security or an obstacle to the application of the present Convention." In general, the occupant can take measures necessary to maintain security, including imposing curfews and censorship, limiting communication and freedom of association, and preventing "political gatherings and parades," that is, peaceful protest against the occupation. Such measures do not violate the Geneva Convention's ban on collective punishment, Dinstein reminds the reader, if they are "directly associated with the exigencies of a specific security situation." Suspected persons can be deported despite the Geneva Convention's ban on deportations (Article 49) because the Israeli courts have held the Convention restricts its stipulation to "Nazi-style" mass deportations. ${ }^{103}$ What is more, the Supreme Court of Israel has stated that the Hague Regulations permit "military commanders to take all necessary action to preserve security," which includes lethal force. ${ }^{104}$ As even proponents of the convergence of IHL and human rights law have to admit, military necessity "functions as a built-in, underlying concept" in the law of belligerent occupation. ${ }^{105}$

Security is given a wide definition to include an obligation for the occupant not 
only to maintain public order but also public life, and indeed the welfare of the population (Regulation 43). The measures that the occupant takes to remedy the distress are the occupant's to decide. ${ }^{106}$ In cases of prolonged occupation, such as in Israel/Palestine, "serious modifications" to the legal system "may become indispensable," lest the society remain in "legal limbo."107 Dinstein continues:

If the constant transformation in everyday technology and communitarian life are ignored by the legislator, the inertia is liable to cause grievous social woes. The present writer takes it as almost axiomatic that the military government must be given more leeway in the application of its lawmaking power if the occupation endures for many years. ${ }^{108}$

Dinstein himself recognizes the transformative consequences of prolonged occupation. As noted above, the influx of colonists is both such a consequence and also a cause of further consequences. Is the settlers' colonization of the West Bank a violation of the Geneva Convention then, as widely believed? In large part it is not, according to Dinstein, and for several reasons. In the first place, the convention does not proscribe voluntary settlement by the occupier's nationals on privately acquired land. Second, settlements are legal if constructed for a "strategic purpose" related to military security; to that extent, they are military settlements that can remain until the occupation ends. Third, while civilian settlements cannot be constructed on forcibly acquired private Palestinian land, they may be constructed on public lands so long as they also serve a security purpose, such as functioning as a lookout, an argument made already in 1967 by Theodor Meron in a celebrated government of Israel memo. ${ }^{109}$ While Dinstein criticizes the Israeli court decisions that authorize this system for mixing military and civilian categories and thereby violating the purpose of IHL, he also notes the courts' insistence that all settlements are in theory temporary and open to evacuation depending on final negotiations with the Palestinians.

To be sure, Dinstein recognizes that observers may regard this qualification with some skepticism, because the settlements appear anything but temporary. His consoling message is that Israel has evacuated tens of thousands of settlers and dismantled their settlements in the Sinai Peninsula, Gaza, and occasionally in the West Bank, so the future remains open. ${ }^{110}$ Indeed, the state can unilaterally evict them because occupant nationals are not protected by IHL. This "grim truth" means that human rights law must fill the gap. "Surely," he pleads, "the irreducible human rights of settlers must be recognized: not because they are settlers, but because they are human beings." What is more, they "are entitled to security of their lives (to be ensured by the military government)" and to have their general needs taken into account. In fact, the colonists are to be counted as part of the occupied population whose welfare the occupant is obliged to ensure. ${ }^{111}$ In this mode, human rights law aids the colonists more than the occupied, because it prioritizes the colonists' security and mobility rights as part of the civilian population, and the occupation context lies beyond its purview, as Aeyal Gross has shown with reference to decisions by the Israeli High Court of Justice. ${ }^{112}$ The measures that Eyal Benvensiti identifies to challenge enduring occupations - international criminal tribunals and commissions of inquiry, invocations of human rights standards by various courts, and international economic 
pressure-have proven impotent in the case of the Israeli occupation of Palestinian territory. ${ }^{113}$

As in early modern cases, it thus becomes an imperative of occupation to intensify itself, now aided by human rights law, leading to the extant process of exponential transformation. ${ }^{114}$ Thus Israeli leaders claim the state must retain the territories conquered in 1967 for security purposes, echoing centuries-old arguments redolent of the briefs, discussed above, for defensive imperialism and defensive conquest. ${ }^{115}$ Even the Interim Agreement on the West Bank and the Gaza Strip ("Oslo II") of 1995 recognized that in the Occupied Territories "Israel shall continue to carry the responsibility for external security, as well as the responsibility for overall security of Israelis for the purpose of safeguarding their internal security and public order." 116

The upshot of these views is that the occupation of the West Bank and Gaza can endure so long as Israel does not sign a peace treaty with its neighbors and with the Palestinians and, further, that it can develop the West Bank in virtually whatever manner it pleases under the pretext of efficient administration and, above all, security. In such circumstances, the occupation is not only prolonged but also deeply transformative. It transcends the provisional and preservationist limitations of belligerent occupation by creating a new order and effective sovereignty. ${ }^{117}$ IHL allows creeping annexation despite the global norm against colonial conquest.

Legal scholars may respond by arguing that the problem lies in Israeli policy rather than the law: colonization of territory is a predictable outcome of the attempt to legally regulate belligerent occupations because occupiers can defy international law, not because the law places no limits on what can be done in the name of security. What is more, international law is less an unequivocal instrument of states than an uneven playing field in which non- or quasi-state actors like the Palestinian Authority appeal to international law, organizations, and courts for redress. Did not the International Court of Justice (ICJ) advise in 2004 that the so-called Israeli Separation Barrier violated international law? ${ }^{118}$ Does not Israel oppose the PA's bid for membership of the International Criminal Court (ICC) because it fears the law's sting?

The historical record and the current Israel-Palestine situation suggest that the international system's asymmetries are reflected in the asymmetry of international law. Notwithstanding the countervailing force of human rights conventions, selfdetermination norms, and the ICC, the law serves more as a handmaiden to state power, including the occupying state, by allowing it to fill the space created by the security exception. ${ }^{19}$ In any event, the ICJ advisory opinion on the Separation Barrier was met with considerable skepticism among legal experts and was of course rejected by the government of Israel; it is legally disputed and politically impotent. ${ }^{120}$ Appeals to security and self-preservation have vouchsafed colonization so far.

Belligerent occupation, a consensus hammered out between sovereign entities at the end of the nineteenth century, is particularly dangerous for occupied peoples that have not (yet) achieved sovereign statehood-like Palestinians or, say, Western Saharans. ${ }^{121}$ To that extent, it is a residue of an imperial global order that distinguishes between those who are full members of the international system and those who are not. The truth that presently dares not speak its name about belligerent occupation was uttered in 1877 by the Russian diplomat F. F. de Martens - the same diplomat 
responsible for the famous humanitarian clause in the preamble to 1899 Hague Convention-in defending his government's occupation and transformation of Bulgaria:

The occupation acquires a different aspect when it is not of a temporary nature but instead annexation is envisioned or the aim of the war itself was to change or ameliorate the organization of a province belonging to the enemy. In this case, the power that executes annexation has the right to transform the ruling institutions and establish order, so as to harmonize them with its political interests or to procure some advantage for the inhabitants. ${ }^{122}$

Annexation was not proscribed in 1877. Even Lieber regarded occupation as akin to conquest and as a prelude to annexation. ${ }^{123} \mathrm{~A}$ diplomat-scholar like Martens, Dinstein can square Israeli intentions with twenty-first-century norms because of the persistence of the security exception. ${ }^{124}$

To be sure, the jus gentium's authorization of defensive conquest was predicated on a logic of just war, in which the rightness of one's jus ad bellum claim determined in part both one's jus in bello and jus post bellum rights, amounting to a legal right to seize territory or property: for example, if one acted in self-defense or in vindication of what Grotius would call a perfect natural right (a language that continued up to Vattel). As a legal language, it differs with contemporary jus ad bellum or jus in bello, in which no territorial rights follow from the legality of one's use of force, and no legal entitlement to change the status of a territory flows from the rights one has an occupant under the contemporary jus in bello. That is the legal reality of this distinction. ${ }^{125}$

The historical reality is that belligerent occupation law provides a stalking horse for much Israeli policy and practice in the occupied territories. While international law does not authorize the permanent alteration of the status of the territory in the way that it certainly would have until 1945 , the law of occupation, which replaced the ancient right of conquest in the late nineteenth and early twentieth centuries, allows that practice to persist despite its preservationist stipulations because of the security exception. ${ }^{126}$

\section{Gaza, Occupation, Self-Determination}

What, then, of the self-determination norm that I noted has shadowed and at times overshadowed colonial occupations for a century? Despite advances like the Additional Protocols, international law still ignores the perspective of the occupied. For the latter, the legal measures instituted by the Israeli occupation authorities are criminal. One (non-Palestinian) commentator goes so far as to denounce them as "terrorism" akin to suicide bombers. ${ }^{127}$ This equation may strike many readers as quixotic, even outrageous, but this assessment by Richard Falk, the international lawyer and sometime UN special rapporteur on human rights in the Palestinian territories, reflects much thinking on the subject outside the North Atlantic world.

Even those who advocate steadfastness in the face of occupation rather than violent resistance, like the West Bank lawyer Raja Shehadeh, have no illusions about its intentions and the role of international law. He noted in 1995 that the Israeli occupation is 
the only one whose entirety has been scrutinized by the ICRC, which oversees the Geneva Conventions, adding that if it ends up presiding over the annexation of Palestinian territories, then their conventions would "have fared miserably as an effective instrument of international law." What is more, any agreement that legalizes this situation "would increase the lure of extremism and religious fundamentalism."128 Many would now call his analysis prescient.

Certainly, groups like Islamic Jihad and Hamas have observed that the path of cooperation and negotiations with Israel has brought Palestinians no further down the road to self-determination, whatever the stipulations of the Oslo Accords. ${ }^{129}$ Similarly, the Goldstone Report on war crimes committed during the 2008-9 Gaza conflict, like the countless criticisms of the Israeli transformative occupation of West Bank, have indeed done little to inhibit Israeli colonization or further attacks on Gaza. ${ }^{130}$ In fact, Islamic Jihad, Hamas, and other resistance groups regard the Israeli withdrawal from Gaza in 2005 as the victory of their military struggle. ${ }^{131}$ Falk puts it another way: the creeping annexation has forced the Palestinians into "a tragic predicament": either to surrender to the annexation, because nonviolent resistance does not halt the construction of settlements, or violently to resist it. ${ }^{132}$ Yet another view would observe that, as throughout imperial history, the persistence of occupation creates the resisting subjectivities that lead to the security imperative, setting up a fatal negative feedback loop. ${ }^{133}$

Supporters of Israel dismiss such arguments by asserting that terrorism causes the occupation, not vice versa. Israel is occupying the West Bank to defend itself and cannot withdraw lest it be hijacked by terrorists and used as a launching pad for still more rockets, insisted Alan Dershowitz, advancing the case made for centuries by Western thinkers who linked expansion with defensive violence. ${ }^{134}$ Echoing Vitoria, Halleck, and Stowell, Dershowitz added that punishing collectives-in this case, civilian Palestinians_-was legitimate because they supposedly supported "the murder of [Israeli] civilians." While he did not advocate deliberately targeting civilians with missiles, he recommended economic sanctions, bulldozing of buildings, and so forth, as legitimate reprisals for their complicity. ${ }^{135}$ Other lawyers like Thane Rosenbaum were less cautious, suggesting that all Gazans were legitimate military targets for the reasons Halleck gave long before. ${ }^{136}$ Rosenbaum was not alone. The notion of Gazan collective guilt for Hamas rockets became a common notion in the summer of 20I4, one used to justify attacks on the entire population. ${ }^{137}$ The Rousseau-Portalis doctrine, which Lemkin noted is "implicit in the Hague Regulations," was abandoned in widespread arguments about Gazans as an enemy people who warranted targeting as a whole. ${ }^{138}$

Might the same be said of the thousands of rockets that Hamas has launched from Gaza into Israel? Are both sides guilty of war crimes? Not according to the Hamas leader Khaled Meshaal: "Our weapons are very basic. We don't have sophisticated arms like Israel. Even if we had them, we wouldn't target civilians. [The Izz ad-Din al-]Qassam brigades, before attacking an area, warn Israeli civilians not to go there."139 It is hard to take such statements seriously. Certainly, Israel can more plausibly claim that its army abides by international law. Israel's bombing of Gaza, declared Dershowitz, was "perfectly 'proportionate,'” citing self-defense, military necessity, and 
efforts to spare civilians, just as the Israeli High Court of Justice has justified the state's practice of assassinating Hamas leaders. ${ }^{140}$ Like Vitoria before him, Dershowitz along with the moral philosopher Michael Walzer defended the deaths of innocent Gazan civilians if they were killed while Israel was engaging in legitimate retaliation: "The fault for all civilian casualties in the Israeli-Palestinian conflict lies exclusively with the Palestinian terrorists, who deliberately create a situation in which civilians will be killed." ${ }^{141}$ The law proscribes the use of "human shields." ${ }^{142}$ In such cases, the proportionality principle allows for greater civilian casualties and must be calculated in view of the expectation of loss and military advantage rather than in light of the actual outcome; it thus makes no legal sense to compare losses on both sides. ${ }^{143}$ As it has for five hundred years, the law of nations entitles the occupier to kill innocents in order to protect itself from violent resistance to its occupation.

As Gaza's armed groups of course understand, and as some Western observers are beginning to realize, were they to launch rockets in open fields and conventionally bear arms according to Geneva stipulations, Palestinians could not militarily challenge the infinitely superior Israeli forces. That does not mean, as the legal scholar Paul Kahn wrote recently, that "the rules of warfare were obviously not written with an eye to violent conflict between state and nonstate forces." It is precisely for this reason that they were written this way. And yet, Kahn is correct that these rules could therefore never realistically regulate the violence of decolonization. In these circumstances of extreme asymmetry, he calls for a new principle of proportionality: one of "overall injury": "The indiscriminate character of the Palestinian rockets is, on this view, not a measure of their illegality, but a measure of their potential effectiveness in inflicting a proportionate injury. The Palestinians hope that the rockets may even the score." ${ }^{144}$ IHL's emphasis on proportionate violence clearly advantages the occupier.

Perhaps because their rockets cannot "even the score," Hamas agreed that the PA join the ICC, thereby effectively recognizing and subjecting itself to international law, as required by the Additional Protocols. ${ }^{145}$ The content of Hamas's national liberation strategy is now uncertain, but its recently released political document shows that it remains committed to armed struggle and argues that it has a right to do so under international law. ${ }^{146}$ Hamas's suspicion of international law so far is no surprise, given that it cannot address the unfinished business of the partition that was forced on Palestine in 1947: the ensuing war and expulsion of Palestinians. ${ }^{147}$ International law is not designed to undermine the global order of states that emerged after 1947. Selfdetermination may be enshrined as a principle in the UN Charter, but not against extant states, as proponents of Biafra discovered when they tried to secede from Nigeria in 1967. The successful Bangladeshi secession from Pakistan in 1971 was won on the battlefield in the teeth of general international opposition. ${ }^{148}$

What, then, does self-determination entail for Gazans and West Bank residents? In the first instance, ending the occupation means ceasing the Israeli (and Egyptian) blockade of Gaza and honoring past ceasefire agreements. When Meshaal says "people have been dying in slow motion since 2006," the year the blockade began, he is referring to the bare life that Gazans are leading. ${ }^{149}$ The first step toward selfdetermination, in other words, might entail less interference rather than nondomination. ${ }^{150}$ But would it end the transformative occupation? To answer that question, 
it is necessary to account for the fact that of the I,499,369 Gazans, I,030,638 are registered as refugees with the United Nations Relief and Works Agency for Palestine Refugees-two-thirds of the population. ${ }^{151}$ According to the UN, most of those who "fled to the Gaza Strip as a result of the 1948 Arab-Israeli war were from Jaffa, towns and villages south of Jaffa, and from the Beersheva area in the Negev." 152 Their fate was the first stage of the demographically transformative occupation of Palestine, now Israel. Their continuing plight enables that project to continue. The same settler colonial process of clearing the land of indigenous people persists in the Negev with the expropriation of Bedouin lands by the Israeli state. ${ }^{153}$ By observing similar processes in many cases, scholars have identified that the inner logic of settler colonialism is the "elimination of the native." 154 Belligerent occupation does not exhaust the occupation regimes to which Palestinians are subject.

Dershowitz might retort that Palestinians and Arabs generally rejected the UN partition plan of 1947 and must therefore bear the consequences of their poor judgment. Such an answer does not ask after the Zionist colonization project in the first place. Like the Spanish about whom Vitoria wrote five hundred years before, Zionists understood their presence in Palestine as a right and Palestinian Arab resistance as illegitimate. They regarded as defensive the colonization of the land in order to demographically overwhelm the local Arab population, despite the fact that it was apparent to all that the local population experienced it as aggressive and expansive. This mode of reasoning persists to the present day.

\section{Conclusion}

Although the right to settle uninhabited land is no longer a legitimate ground for imperial expansion, its cultivation and improvement still possess a powerful hold over the Western imagination. The Israeli colonists trump the Palestinian right of selfdetermination in the minds of those who identify the Palestinians with "red Indians" and associate the colonists (many of whom are United States citizens) with their forebears who conquered the North American interior. It is no accident that both sides in Israel/Palestine invoke this frontier analogy. "We are not red Indians," declared Yasser Arafat, implying that Palestinians could not be exterminated or driven off their ancestral land. ${ }^{155}$ Others averred the contrary: "Even the great American democracy could not have been created without the annihilation of the Indians," the Israeli historian Benny Morris told an interviewer in 2004. "There are cases in which the overall, final good justifies harsh and cruel acts that are committed in the course of history." ${ }^{156}$ Echoes of the nineteenth-century North American discourse about savage Indians and manifest destiny are not difficult to hear. The Palestinians can indeed be dispossessed and, as before, international law will not stand in the way of occupiers. When Israeli leaders say that their punitive measures are responses to the terroristic resistance of the occupied people, international law largely justifies them and their various transformative occupation regimes-West Bank, Gaza, and Israel itself - in the name of security and self-defense. ${ }^{157}$ For this reason, critical observers like Richard Falk propose a new international convention to ensure that occupiers withdraw as soon as possible and do not inhibit the self-determination of the occupied; and, in the case of prolonged occupation, that mechanisms are institutionalized-like a ten-year 
limit— to ensure such a withdrawal. Even this proposal does not address the security exception. ${ }^{158}$

Lemkin already addressed the relevant lacuna in IHL in 1944. The Hague Regulations covered individuals rather than peoples whose protection, let alone right of selfdetermination or autonomy, was unaddressed. The regulations did not proscribe the "various ingenious measures for weakening or destroying political, social, and cultural elements in national groups." 159 He recommended that they be amended in two ways:

In the first should be included every action infringing upon the life, liberty, health, corporal integrity, economic existence, and the honor of the inhabitants when committed because they belong to a national, religious, or racial group; and in the second, every policy aiming at the destruction or the aggrandizement of one such group to the prejudice or detriment of another. ${ }^{160}$

Herewith, he hoped to outlaw genocide, which, we recall, he defined broadly as a technique of occupation that destroyed, disintegrated, and weakened an enemy nation. Accordingly, in Axis Rule in Occupied Europe, he posited genocide as a colonial formation:

Genocide has two phases: one, destruction of the national pattern of the oppressed group; the other, the imposition of the national pattern of the oppressor. This imposition, in turn, may be made upon the oppressed population which is allowed to remain, or upon the territory alone, after removal of the population and the colonization of the area by the oppressor's own nationals. ${ }^{161}$

This approach was taken up in one of the subsequent Nuremberg Trials-the socalled Race and Settlement (RuSHA) trial of fourteen Nazis officials-which, following Lemkin, defined genocide not only in terms of Nazi mass killing of Jews but also of Nazi expansionism (Lebensraum) and colonization practices. In fact, they were linked, the latter representing the causal context for the former. But not for long; during the other trials and UN negotiations for an international convention on genocide between 1946 and 1948, any suggestion that genocide would entail weakening — as opposed to physically destroying — a group, still less criminalizing the colonial aggrandizement of one group at the expense of another, was removed. ${ }^{162} \mathrm{~A}$ law with counterhegemonic potential was rendered a tool of the postwar order of population expulsions and transfers. ${ }^{163}$

Lemkin also called for international supervision of occupations in the form of an agency that could inspect occupied countries for how "the occupant treats nations in prison." Otherwise, the cultural destruction would be irremediable. ${ }^{164}$ While the Fourth Geneva Convention provides machinery for supervision by the ICRC, it seems impotent. ${ }^{165}$ A believer in international law to the last, Lemkin was too optimistic about the impact such oversight might have when other provisions of the Hague Regulations were not also reformed. Nazi-style imperialism and colonization, which flouted IHL, was unnecessary for conquest and annexation. They could and can be achieved without the interdiction of international law. 
For comments on drafts of this essay, my thanks are extended to Mohammed Abed, Hannah Ashmawi, Seth Anziska, Bashir Bashir, Nehal Bhuta, Alon Confino, Raffaella Del Sarto, Richard Devetak, Jost Dülffer, Andrew Fitzmaurice, Peter Holquist, Simon Jackson, Nathan Kurz, Michelle Lesh, Yotam Hotam, Liam McHugh-Russell, Hadassa Noorda, Gabriel Piterberg, Daniel Marc Segesser, Martin Shaw, Alecia Simmonds, Boyd van Dijk, Simon Taylor, Lorenzo Veracini, and Patrick Wolfe. None are responsible for the arguments or any errors.

I. Joint Statement by President Roosevelt and Prime Minister Churchill, August I4, I94I, accessed September 2, 20I4, http://avalon.law.yale.edu/wwii/atio.asp.

2. Raphael Lemkin, Axis Rule in Occupied Europe (Washington, D.C.: Carnegie Endowment for International Peace, 1944), 8I, xi (emphasis added).

3. Lemkin, Axis Rule in Occupied Europe, 8o. Cf. Jeff McMahan, Killing in War (Oxford: Oxford University Press, 2009), 80; Helen M. Kinsella, The Image before the Weapon: A Critical History of the Distinction between Combatant and Civilian (Ithaca, N.Y.: Cornell University Press, 20II), II; Eyal Benvenisti, The International Law of Occupation, 2nd ed. (Oxford: Oxford University Press, 20I2), 24.

4. Mark A. Lewis, The Birth of the New Justice (Oxford: Oxford University Press, 20I4).

5. Elizabeth Borgwardt, A New Deal for the World: America's Vision for Human Rights (Cambridge, Mass.: Harvard University Press, 2005), 177-79.

6. Mark Mazower, No Enchanted Palace: The End of Empire and the Ideological Origins of the United Nations (Princeton, N.J.: Princeton University Press, 2009).

7. On development, see Frederick Cooper, "Reconstructing Empire in British and French Africa," Past \& Present 2IO, suppl. 6 (20II): 196-20I. During the war, some liberal commentators defended Western Europe's colonial empires against increasing criticism: W. K. Hancock, Argument of Empire (New York: Penguin Books, 1943), and Hans Kohn, World Order in Historical Perspective (Cambridge, Mass.: Harvard University Press, 1942).

8. Mazower, No Enchanted Palace, 165-67; Erez Manela, The Wilsonian Moment: SelfDetermination and the International Origins of Anticolonial Nationalism (Oxford: Oxford University Press, 2007).

9. Glenda Sluga, Nationalism in the Age of Internationalism (Philadelphia: University of Pennsylvania Press, 2013), 80.

Io. Kwame Nkrumah, Africa Must Unite or Perish (New York: Frederick A. Praeger, 1963), ix.

II. Kinsella, The Image before the Weapon.

I2. Jost Dülffer, "Die Diskussion um das Selbsbestimmungsrecht und die Friedensregelungen nach den Weltkriegen des 20. Jahrhunderts," in Die Verteilung der Welt: Selbstbestimmung und das Selbst-bestimmungsrecht der Völker, ed. Jörg Fisch (Munich: R. Oldenbourg Verlag, 20II), II3-39; Bradley Simpson, "Self-Determination, the End of Empire and the Fragmented Discourse of Human Rights in the 1970s," Humanity 4, no. 2 (Summer 2013): 239-60.

I3. Steven R. Ratner, "Foreign Occupations and International Territorial Administration: The Challenges of Convergence," European Journal of International Law 16, no. 4 (September 2005): 695-96. Cf. Roland Burke, Decolonization and the Evolution of International Human Rights (Philadelphia: University of Pennsylvania Press, 2010).

14. Lemkin, Axis Rule in Occupied Europe, passim. A comprehensive treatment of occupation 
in the law of nations and international law is Andrew Fitzmaurice, Sovereignty, Property, and Empire, I500-2000 (Cambridge: Cambridge University Press, 20I4).

I5. Adam Roberts, "Transformative Military Occupations: Applying the Laws of War and Human Rights," American Journal of International Law 100, no. 3 (July 2006): 580-622. Further discussion of the concept is contained in the introduction to this dossier.

I6. Typical in distinguishing belligerent occupation and transformative occupation is Andrea Carcano, The Transformation of Occupied Territory in International Law (Boston: Brill Nijhoff, 2015), 37, 73 .

17. On the Israeli occupation, see "The Separation Barrier," B’Tselem, accessed July Io, 20I6, http://www.btselem.org/separation_barrier.

18. Ian S. Lustick, "Israel and the West Bank after Elon Moreh: The Mechanics of De Facto Annexation," Middle East Journal 35, no. 4 (Autumn 198I): 557-77. I leave to one side the fact that Israel purported to annex Jerusalem and adjacent areas after 1967. Yael Yishai, "Israeli Annexation of East Jerusalem and the Golan Heights: Factors and Processes," Middle Eastern Studies 2I, no. I (January 1985): 45-60.

19. See the dossier introduction for elaboration.

20. Hamada Zahawi, "Redefining the Laws of Occupation in the Wake of Operation Iraqi Freedom" California Law Review 95, no. 6 (December 2007), 2295-352.

2I. Adam Roberts, "Prolonged Military Occupation: The Israeli-Occupied Territories since 1967," American Journal of International Law 84, no. I (January 1990): 44-103.

22. Allan Gerson, "Trustee-Occupant: The Legal Status of Israel's Presence in the West Bank," Harvard International Law Journal I4 (Winter 1973): 2, 46.

23. Allan Gerson, "War, Conquered Territory and Military Occupation in the Contemporary International Legal System," Harvard International Law Journal 18, no. 3 (Summer 1977): 525-56.

24. Roberts, "Prolonged Military Occupation," IO2-3.

25. For example, Human Rights Watch, Why They Died: Civilian Casualties in Lebanon during the 2006 War I9, no. 5(E), September 2007, accessed September I, 2009, http://www.hrw.org/sites/ default/files/reports/lebanono907.pdf; and Human Rights Watch, Civilians under Assault, vol. I9, No. 3(E), August 2007, accessed September I, 2009, http://www.hrw.org/sites/default/files/reports/ iopto807.pdf.

26. George E. Bisharat, "Israel Is Committing War Crimes," Wall Street Journal, January io, 2009; Bisharat, "Land, Law, and Legitimacy in Israel and the Occupied Territories," American University Law Review 43, no. 2 (Winter 1994): 467-561; W. Thomas Mallison and Sally V. Mallison, The Palestine Problem in International Law and World Order (London: Longman, 1986); Emma Playfair, ed., International Law and the Administration of Occupied Territories (Oxford: Clarendon, 1992); Victor Kattan, From Coexistence to Conquest: International Law and the Origins of the Arab-Israeli Conflict, I89I-I949 (London: Pluto, 2009). Even the Boycott, Divestment, and Sanctions movement places its trust in international law: http://www.bdsmovement.net (accessed September I, 20I4).

27. For a discussion of the general legal issues, see Nehal Bhuta, "New Modes and Orders: The Difficulties of a Jus Post Bellum of Constitutional Transformation," University of Toronto Law Journal 6o, no. 3 (Summer 2010): 799-854.

28. I owe this formulation to Nehal Bhuta.

29. J. A. North, "The Development of Roman Imperialism," Journal of Roman Studies $7 \mathrm{I}$ (198I): I-9. On the notion of defensive war in Roman thought, see Richard Tuck, The Rights of 
War and Peace: Political Thought and the International Order from Grotius to Kant (Oxford: Oxford University Press, 1999).

30. Karl Jacoby, "'The Broad Platform of Extermination': Nature and Violence in the Nineteenth Century North American Borderlands," Journal of Genocide Research Io, no. 2 (June 2008): 253 .

3I. John R. Seeley, The Expansion of England (1883; Chicago: University of Chicago Press, I97I ), I2.

32. Cf. Lauren Benton and Benjamin Straumann, "Acquiring Empire by Law: From Roman Doctrine to Early Modern European Practice," Law and History Review 28, no. I (February 2010): I-38.

33. Symptomatic is Theodor Meron, "The Humanization of Humanitarian Law," American Journal of International Law 94, no. 2 (April 2000): 239-78.

34. Cf. Carl Schmitt, Four Chapters on the Concept of Sovereignty, trans. George Schwab (Cambridge, Mass.: MIT Press, 1988); Nasser Hussain, The Jurisprudence of Emergency: Colonialism and the Rule of Law (Ann Arbor: University of Michigan Press, 2003). For the Israeli occupation as an emergency regime, see Orna Ben-Naftali, Aeyal M. Gross, and Keren Michaeli, "Illegal Occupation: Framing the Occupied Palestinian Territory," Berkeley Journal of International Law 23, no. 3 (2005): 55I-6I4.

35. I myself follow Antony Anghie, Imperialism, Sovereignty, and the Making of International Law (Cambridge: Cambridge University Press, 2004) in beginning in the sixteenth century.

36. Patrick Wolfe, "Corpus Nullius: The Exception of Indians and other Aliens in US Constitutional Discourse," Postcolonial Studies I0, no. 2 (2007): 130.

37. Martti Koskenniemi, "International Law and Raison d'état: Rethinking the Prehistory of International Law," in The Roman Foundations of the Law of Nations: Alberico Gentili and the Justice of Empire, ed. Benedict Kingsbury and Benjamin Straumann (Oxford: Oxford University Press 2010), 297.

38. Reinhart Koselleck, "Linguistic Change and the History of Events," Journal of Modern History 6I, no. 4 (December 1989): 649-66.

39. The literature on these subjects is voluminous and does not require explication here. Recent titles include Fitzmaurice, Sovereignty, Property, and Empire, I500-200o; Benvenisti, The International Law of Occupation; Ingrid Detter De Lupis, The Law of War, 2nd ed. (Cambridge: Cambridge University Press, 200o); Peter Holquist, By Right of War: Imperial Russia and the Development of the Law of War (forthcoming).

40. Cf. Richard Falk, "Some Legal Reflections on Prolonged Israeli Occupation of Gaza and the West Bank," Journal of Refugee Studies 2, no. I (1989): 40-51. The extensive literatures on Zionism as a settler-colonial movement and as a movement that collaborated with British imperialism are not concerned with occupation as such. In the place of many citations, see Lorenzo Veracini, Israel and Settler Society (London: Pluto Press, 2006), the journal he co-founded, Settler Colonial Studies, as well as Shira Robinson, Citizen Strangers: Palestinians and the Birth of Israel's Liberal Settler (Stanford, Calif.: Stanford University Press, 2013), and Michael J. Cohen, "Zionism and British Imperialism II: Imperial Financing in Palestine," Journal of Israeli History 30, no. 2 (September 20II): II5-39.

41. James Brown Scott, The Spanish Origin of International Law: Francisco de Vitoria and His Law of Nations (Oxford: Clarendon Press, 1934); Robert A. Williams, The American Indian in Western Legal Thought: The Discourses of Conquest (Oxford: Oxford University Press, 1992); Andrew 
Fitzmaurice, Humanism and America: An Intellectual History of English Colonisation, I500-I625

(Cambridge: Cambridge University Press, 2003). A reservation about such a search for origins is David W. Kennedy, "Primitive Legal Scholarship in International Law," Harvard International Law Journal 27, no. I (Winter 1986): I-27.

42. William Bain, "Saving the Innocent, Then and Now: Vitoria, Dominion and World Order," History of Political Thought 34, no. 4 (Winter 2013): 588-613.

43. Andrew Fitzmaurice, "Anticolonialism in Western Political Thought: The Colonial Origins of the Concept of Genocide," in Empire, Colony, Genocide: Conquest, Occupation and Subaltern Resistance in World History, ed. A. Dirk Moses (New York: Berghahn Books, 2008), 55-80.

44. My argument has points of contact with Antony Anghie's justly famous book Imperialism, Sovereignty, and the Making of International Law. I focus more on the concept and laws of occupation and the right of indigenous resistance. See also Kinsella, The Image before the Weapon, $53-70$.

45. Anghie, Imperialism, Sovereignty, and the Making of International Law, 28, 293-95.

46. Francisco de Victoria, De Indis et de Ivre Belli Reflectiones, ed. Ernest Nys (Washington D.C.: Carnegie Institution, 1917), I5I.

47. Ibid., I54-55.

48. Ibid., I7I.

49. Tuck, The Rights of War and Peace.

50. Annabel S. Brett, Changes of State: Nature and the Limits of the City in Early Modern Natural Law (Princeton, N.J.: Princeton University Press, 20II).

51. Emer de Vattel, The Law of Nations or, Principles on the Law of Nature Applied to the Conduct and Affairs of Nations and Sovereigns, ed. Joseph Chitty (Philadelphia: Johnson and Co., 1867), 318 .

52. Ibid., 319 .

53. Ibid., 318 .

54. Ibid., I44.

55. Ibid., $445-45$.

56. Ian Hunter, "Vattel in Revolutionary American: From the Rules of War to the Rule of War," in Between Indigenous and Settler Governance, ed. Lisa Ford and Tim Rowse (Abingdon: Routledge, 2013), 12-22.

57. Francis Lieber, "Guerrilla Parties Considered with References to the Laws and Usages of War," in Miscellaneous Writings, 2 vols. (Philadelphia, J. B. Lippincott, I88o), I:284-85. This essay, published in 1862, appeared before his famous code of 1863. On Lieber, see John Fabian Witt, Lincoln's Code: The Laws of War in American History (New York: Free Press, 2012).

58. Lieber, "Guerrilla Parties Considered with References to the Laws and Usages of War," 286.

59. Michael Walzer continues this line of reasoning in Just and Unjust Wars: Moral Argument with Historical Illustrations (New York: Basic Books, 1977), 205, where he writes that the "revolutionary reveals his freedom in the same way as he earns it, by directly confronting his enemies and refraining from attacks on anyone else's" (emphasis added).

6o. Witt, Lincoln's Code, 92-93, 96, 106, 337, 355-58; Jacoby, " 'The Broad Platform of Extermination," " 260. Kinsella, The Image before the Weapon, 98-10I.

6I. Paul A. Kramer, The Blood of Government: Race, Empire, and the United States and the 
Philippines (Chapel Hill: University of North Carolina Press, 2006), 90, IOI, 136-37; Stuart Creighton Miller, Benevolent Assimilation: The American Conquest of the Philippines (New Haven, Conn.: Yale University Press, 1984), 88; Christopher J. Einolf, America in the Philippines, I899-1902: The First Torture Scandal (Basingstoke: Palgrave MacMillan, 20I4).

62. Henry Wager Halleck, "Retaliation in War," American Journal of International Law 6, no. I (I864; January I9I2): I08.

63. Ibid., I08.

64. Ibid., III-I2.

65. Ibid., IIO.

66. Glenn A. May, "Filipino Resistance to American Occupation: Batanguas, I899-1902," Pacific Historical Review 48, no. 4 (November 1979): 53I-56. Moses, Empire, Colony, Genocide.

67. Heinrich von Treitschke, Politics (New York: Macmillan, 1916), I:613.

68. Cf. Isabel Hull, Absolute Destruction: Military Culture and the Practices of War in Imperial Germany (Ithaca, N.Y.: Cornell University Press, 2004), IIO-30. On the appreciation of these facts by the legal community, cf. Daniel Marc Segesser, Recht statt Rache oder Rache durch Recht? Die Ahndung von Kriegsverbrechen in der internationalen wissenschaftlichen Debatte, 1872-1945

(Paderborn: Ferdinand Schöningh, 2010), 86-89.

69. Michael Lieven, "'Butchering the Brutes All over the Place': Total War and Massacre in Zululand in 1879," History 84 (October 1999): 614-32.

70. Lassa Oppenheim, International Law: A Treatise, vol. I, Peace, 2nd ed. (New York: Longmans, Green and Co., 1912), vol. 2, War, 167. The first edition appeared in 1905 and 1906. Generally, see Martti Koskenniemi, The Gentle Civilizer of Nations: The Rise and Fall of International Law, 1870-1960 (Cambridge: Cambridge University, 200I), 98-166

7I. Oppenheim, International Law, 297.

72. Peter Holquist, "By Right of War: Imperial Russia and the Development of the Law of War" (paper presented at the History of the Laws of War workshop, European University Institute, January 23, 2015); Witt, Lincoln's Code, 343, 349-50.

73. Ben Clarke, "The Juridical status of Civilian Resistance to Foreign Occupation under the Laws of Nations and Contemporary International Law," University of Notre Dame Australia Law Review 7 (December 2005): I-22.

74. The Martens Claus and the Laws of Armed Conflict, ICRC Resource Centre, accessed August 24, 20I4, https://www.icrc.org/eng/resources/documents/misc/57jnhy.htm.

75. John Westlake, International Law (Cambridge: Cambridge University Press, 1907), 55.

76. Ibid., 76 .

77. John Westlake, Chapters on the Principles of International Law (Cambridge: Cambridge University Press, 1894), 238, 24I-44, does not approve of the distinction but his reasoning is unconvincing.

78. A. E. Borton, "The Use of Aircraft in Small Wars," Journal of The Royal United Service Institute 65 (May 1920): 310-19; J.A. Chamier, "The Use of the Air Force for Replacing Military Garrisons," Royal United Service Institution Journal 66 (May 1921): 205-16; J. B. Glubb, "Air and Ground Forces in Punitive Expeditions," Royal United Service Institution Journal 7I (August 1926): 777-84; Arnold Wilson, "The Laws of War in Occupied Territory," Transactions of the Grotius Society I8 (1932): 28. Wilson ran the civil administration for the British in Mesopotamia between 1918 and 1920 and reflected on his experiences in this article. James Garner, "Proposed Rules for the Regulation of Aerial Warfare," American Journal of International Law i8 (January 1924): 56-8I; 
Michael Paris, “Air Power in Imperial Defence, I880-1918," Journal of Contemporary History 24, no. 2 (April 1989): 209-25.

79. Richard H Peck, "Aircraft in Small Wars," Journal of the Royal United Service Institution 73, no. 49I (August 1928): 543 .

8o. Ellery C. Stowell, "Military Reprisals and the Sanctions of the Laws of War," American Journal of International Law 36, no. 4 (October 1942): 646-47, 650. The occupier could use "whatever effective means of prevention or repression they may have at their disposal" to fight guerrilla warfare.

8I. Ibid., 650. On the issue of savagery, law, organized justice, and revenge, see also Segesser, Recht statt Rache oder Rache durch Recht?, 15-23.

82. Alfred Streim, "International Law and Soviet Prisoners of War," in From Peace to War: Germany, Soviet Russia and the World, I939-194I, ed. Bernd Wegner (Providence: Berghahn Books, I997), 293-308. The USSR offered to be bound by the Hague Regulations and 1929 Geneva Convention at the beginning of the Nazi campaign, but the German government did not respond to the entreaty. See Alfred Streim, Die Behandlung sowjetischer Kriegsgefangener im "Fall Barbarossa" (Heidelberg: C. F. Müller Juristischer Verlag, 198I), 33-34.

83. Kevin Jon Heller, The Nuremberg Military Tribunals and the Origins of International Criminal Law (Oxford: Oxford University Press, 2013), 309-Iо.

84. Jörg Ganzenmüller, Das belagerte Leningrad, I94I-1944: Die Stadt in den Strategien von Angreifern und Verteidigern (Paderborn: Ferdinand Schönigh, 2005). Thanks to Daniel Marc Segesser for this reference.

85. Heller, The Nuremberg Military Tribunals and the Origins of International Criminal Law, 207-IO, 38I.

86. Geoffrey Best, War and Law since 1945 (Oxford: Clarendon Press, 1997).

87. William I. Hitchcock, "Human Rights and the Laws of War: The Geneva Conventions of 1949," in The Human Rights Revolution: An International History, ed. Akira Iriye, Petra Goedde, and William I. Hitchcock (Oxford: Oxford University Press, 20II), 99-IOo.

88. Resolution 2535 on December I0, 1969, and Resolution 2672 on December 8, I970.

89. The last quotations are taken from Gen. Ass. Res. 2649 (XXV), November 30, 1970. See also Shaw J. Dallal, "Israeli Human Rights Violations and Palestinian Violence," Syracuse Journal of International Law and Commerce I4, no. 2 (Winter 1987): 109-24, who argues a Palestinian right to resistance based on these General Assembly resolutions.

90. Georges Abi-Saab, "Wars of National Liberation and the Laws of War," Annales d'études Internationales 3 (1972): IOO, III.

91. Detter De Lupis, The Law of War, 55 .

92. Antonio Cassese, "Wars of National Liberation and Humanitarian Law," in The Human Dimension of International Law: Selected Papers of Antonio Cassese (Oxford: Oxford University Press, 2008), IOO.

93. Protocol Additional to the Geneva Conventions of August 12, 1949, and relating to the Protection of Victims of International Armed Conflicts (Protocol I), June 8, 1977, accessed August 20, 20I4, www.icrc.org/ihl.nsf/7c4do8d9b287a42I4I256739003e636b/f6c8b9feeI4a77fdci2564I eoos2bo79.

94. Cassese, "Wars of National Liberation and Humanitarian Law," IOo-IOI.

95. Sibylle Scheipers, "Fighting Irregular Fighters: Is the Law of Armed Conflict Outdated?," Parameters 43, no. 4 (Winter 20I3-I4): 52. 
96. Heather A. Wilson, International Law and the Use of Force by National Liberation Movements (Oxford: Oxford University Press, 1990), I33; Cassese, "Wars of National Liberation and Humanitarian Law," IO3.

97. David Kretzmer, The Occupation of Justice: The Supreme Court of Israel and the Occupied Territories (Albany: State University of New York Press, 2002), 36.

98. The "Declaration of Principles on Interim Self-Government Arrangements" signed by the Palestine Liberation Organisation and State of Israel in 1993 does not mention self-determination. See the analysis by Antonio Cassesse, "The Israel-PLO Agreement and Self-Determination," European Journal of International Law 4, no. 4 (1993): 564-71. The Israeli position is put by Yehuda Z. Blum, "The Missing Reversioners: Reflections on the Status of Judea and Samaria," Israel Law Review 3, no. 2 (April 1968): 279-30I, and Rostow, "Palestinian Self-Determination."

99. Yoram Dinstein, “Israel's Benign Occupation," Jerusalem Post, June 2, 1972. Thanks to Nathan Kurz for sharing this article.

Ioo. He has worked at North American universities and held fellowships there and in Germany; his books are widely cited and published by the leading academic presses; he is the founding editing of the Israel Yearbook on Human Rights, was dean of law of Tel Aviv University, among many such leadership positions. Yoram Dinstein, The International Law of Belligerent Occupation (Cambridge: Cambridge University Press, 2009), 2. He hopes that his book might serve as a training manual for officers; Dinstein, War, Aggression, and Self-Defence, $4^{\text {th }}$ ed. (Cambridge: Cambridge University Press, 2005).

IOI. Yoram Dinstein, The Conduct of Hostilities under the Law of International Armed Conflict (Cambridge: Cambridge University Press, 2004), 20; Dinstein, The International Law of Belligerent Occupation, 35 .

I02. Noura Erekat, "No, Israel Does Not Have the Right to Self-Defense in International Law against Occupied Palestinian Territory," Jadaliyya, July II, 20I4, accessed August 24, 20I4, http://www.jadaliyya.com/pages/index/8799/no-israel-does-not-have-the-right-to-self-defense-.

I03. Dinstein, The International Law of Belligerent Occupation, 94, 63-64, IIO-I3, I55-56, I63-70, I72-73.

I04. Quoted in Iris Canor, "When Jus ad Bellum Meets Jus in Bello: The Occupier's Right of Self-Defence against Terrorism Stemming from Occupied Territories," Leiden Journal of International Law I9, no. I (March 2006): I46.

I05. Yutaka Arai-Takahashi, The Law of Occupation: Continuity and Change in International Humanitarian Law, and Its Interaction with International Human Rights Law (Leiden: Martinus Nijhoff, 2009), 662, quoting Dinstein to the effect that that states enjoy "much leeway" regarding military necessity.

I06. Dinstein, The International Law of Belligerent Occupation, 93-94.

I07. Ibid., II6-I7.

I08. Ibid., I20 (emphasis added).

I09. Theodor Meron, Legal Adviser, Ministry of Foreign Affairs, to Yafeh, Political Secretary to the Prime Minister, Subject: Settlement in the Administered Territories, September 18, I967, translation at: http://www.soas.ac.uk/lawpeacemideast/resources/file48485.pdf. This memo is often mis-cited as informing the government about the illegality of settling the conquered territories in the 1967 war.

IIO. Dinstein, The International Law of Belligerent Occupation, 240-47.

III. Ibid., I30. 
II2. Ibid., 286; Aeyal Gross, "Human Proportions: Are Human Rights the Emperor's New Clothes of the International Law of Occupation," European Journal of International Law I8, no. I (February 2007): I-35; Aeyal Gross, "The Righting of the Law of Occupation," in The Frontiers of Human Rights: Extraterritoriality and its Challenges, ed. Nehal Bhuta (Oxford: Oxford University Press, 20I6), 2I-54. Dinstein would have no truck with arguments that integrate IHL into the socalled human rights revolution as proposed by Hitchcock, "Human Rights and the Laws of War," and Robert Kolb and Richard Hyde, An Introduction to the International Law of Armed Conflicts (Oxford: Hart Publishing, 2008), 269. Philip Spoerri, "The Law of Occupation," in Oxford Handbook of International Law in Armed Conflict, ed. Andrew Clapham and Paola Gaeta (Oxford: Oxford University Press, 2014), I82-205, also expresses Dinstein-like skepticism. But see Adam Roberts, "The Applicability of Human Rights Law during Military Occupations," Review of International Studies 13, no. I (January 1987): 39-48.

II3. Benvenisti, The International Law of Occupation, 3I8.

II4. Cf. Lorenzo Veracini, "The Other Shift: Settler Colonialism, Israel, and the Occupation,” Journal of Palestine Studies 42, no. 2 (Winter 2013): 33.

II5. Stephen M. Schwebel, "What Weight to Conquest?," American Journal of International Law 64, no. 2 (April 1970): 347; Naftali Bennett, "For Israel, Two States Is No Solution,” New York Times, November 5, 20I4. Proposing a softer view, Dinstein's colleague Eyal Benvenisti has shrewdly suggested that, although international law does not recognize enduring occupations as illegal, the occupant's refusal to sincerely come to peaceful terms should render it so because such obstructionism "should be considered outright annexation" of the territory-and annexation remains illegal. Ultimately, however, he, too, thinks that security concerns are a legitimate reason for an occupant to hold onto territory. Benvenisti, The International Law of Occupation, I46-47.

II6. Chapter 2, Article X, Clause 4 of the Interim Agreement on the West Bank and the Gaza Strip, signed in Washington, DC, September 28, I995, accessed December I, 20I4, http://www .mfa.gov.il/MFA/ForeignPolicy/Peace/Guide/Pages/THE\%2oISRAELI-PALESTINIAN\%2o INTERIM\%20AGREEMENT.aspx.

II7. Israeli Ministry of Foreign Affairs runs this line of argument, citing Eugene V. Rostow: "Israeli Settlements and International Law," May 20, 200I, accessed August I4, 20I4, http:// www.mfa.gov.il/mfa/foreignpolicy/peace/guide/pages/israeli\%2osettlements\%2oand\%20 international\%2olaw.aspx. Cf. Bhuta, “The Antimonies of Transformative Occupation,” 737.

II8. Legal Consequences of the Construction of a Wall in the Occupied Palestinian Territory, accessed November 2I, 20I4, http://www.icj-cij.org/docket/index.php?pI $=3 \&$ p2 $=4 \&$ case $=\mathrm{I} 3 \mathrm{I} \&$ $\mathrm{p} 3=4$.

II9. Cf. Jack Goldsmith and Eric A. Posner, The Limits of International Law (Oxford: Oxford University Press, 2005).

I20. Roberts, “Transformative Military Occupation,” 597.

I2I. Abdeslam Maghraoui, "Ambiguities of Sovereignty: Morocco, The Hague and the Western Sahara Dispute," Mediterranean Politics 8, no. I (Spring 2003): II3-26.

I22. Cited in Benvenisti, "The Origins of the Concept of Belligerent Occupation," 646 (emphasis added).

I23. Rotem Giladi, "A Different Sense of Humanity: Occupation in Francis Lieber's Code," International Review of the Red Cross 94, no. 885 (Spring 20I2): II3.

I24. The existence of the security exception in other conventions is noteworthy, such as the I954 Hague Convention for Protection of Cultural Property, whose Articles 4.2 and II.2 permit 
destruction of cultural permit when military necessity requires it. See Gary D. Solis, The Law of Armed Conflict: International Humanitarian Law in War (Cambridge: Cambridge University Press, 2010), 559-60.

I25. Thanks to Nehal Bhuta for clarification on these distinctions.

I26. Ian Brownlie, International Law and the Use of Force by States (Oxford: Clarendon, 1963); Roman Boed, "State of Necessity as a Justification for Internationally Wrongful Conduct," Yale Human Rights and Development Law Journal 3 (2000): I-45.

I27. Richard Falk, "Azmi Bishara, the Right of Resistance, and the Palestinian Ordeal," Journal of Palestine Studies 3I, no. 2 (Winter 2002): 2I.

I28. Raja Shehadeh, "The Geneva Convention and the Autonomous Territories: A

Rejoinder," Security Dialogue 26, no. 2 (June 1995): 183.

I29. Curiously, Michael Walzer agrees: Walzer, "Israel Must Defeat Hamas, But Also Must Do More to Limit Civilian Deaths," New Republic, July 30, 2014.

130. Report of the United Nations Fact-Finding Mission on the Gaza Conflict, A/HRC/12/48, September 25, 2009 (the "Goldstone Report").

I3I. Mouin Rabbani, "Between Hamas and the PA: An Interview with Islamic Jihad's Khalid Al-Batsh," Journal of Palestine Studies 42, no. 2 (Winter 2013): 6I-70. See Tareq Baconi's essay in this issue. See also Daniel Levy, "Gaza Demilitarization Won't Solve Israeli-Palestinian Conflict," Al-Monitor, August I4, 2014.

I32. Falk, "Azmi Bishara, the Right of Resistance and the Palestinian Ordeal," 29, 39. This predicament, confined to Palestine in Falk's analysis, may be generalized to settler-indigenous relations over the centuries. To this extent, to single out the Middle East as law-free zone mistakes a global condition for a regional peculiarity: Jean Allain, "Orientalism and International Law: The Middle East as Underclass of the International Legal Order," Leiden Journal of International Law I7, no. 2 (June 2004): 39I-404.

I33. Cf. Avram Bornstein, "The Military Occupation as Carceral Society: Prison, Checkpoints, and Walls in the Israeli-Palestinian Struggle," Social Analysis 52, no. 2 (Summer 2008): Io6-30; Yousef Alhelou, "In Gaza, Palestinians Celebrate Resistance and Credit It with 'Victory," Mondoweiss, August, 28, 20I4, accessed September I, 20I4, http://mondoweiss.net/20I4/o8/ palestinians-celebrate-resistance.html.

134. Alan M. Dershowitz, "Terrorism Causes Occupation, Not Vice Versa," Huffington Post, August II, 2006.

135. Alan M. Dershowitz, Why Terrorism Works (New Haven, Conn.: Yale University Press, 2002), I74-75.

136. Thane Rosenbaum, "Hamas's Civilian Death Strategy," Wall Street Journal, July 2I, 2014. A considered view of complicity is Christopher Kutz, Complicity: Ethics and Law for a Collective Age (Cambridge: Cambridge University Press, 2007).

137. For example, Giora Eiland, a major general in the Israeli army and former national security advisor to the Israeli government, urged that all Gazan civilians suffer because "they are to blame for this situation just like Germany's residents were to blame for electing Hitler as their leader and paid a heavy price for that, and rightfully so." Giora Eiland, "In Gaza, There Is No Such Thing as 'Innocent Civilians,'” Yedioth Ahronoth, August 5, 20I4; Shlomi Eldar, "To Stop Hamas, Israel Should Cut Electricity and Supplies to Gaza," Al-Monitor, August 2I, 20I4. Take the famous writer Cynthia Ozick, who declared that Gazan "'civilian homes' are weapons depots; 
or else they are outlets, sometimes with complicit families still in them, concealing tunnels dug from Egypt to Gaza”: Cynthia Ozick, “Martyrs,” New Republic, December II, 2006.

138. Lemkin, Axis Rule in Occupied Europe, 8o.

139. Asli Aydintasbas interview with Khaled Meshaal: "Meshaal: We Fight because We Are under Occupation," Al-Monitor, August 24, 2014.

I40. Alan M. Dershowitz, "Israel's Policy Is Perfectly 'Proportionate,'” Wall Street Journal, January 2, 2009; Walzer, "Israel Must Defeat Hamas, But Also Must Do More to Limit Civilian Deaths”; Michelle Lesh, “The Public Committee against Torture in Israel v. The Government of Israel: The Israeli High Court of Justice Targeted Killing Decision,” Melbourne Journal of International Law 8, no. 2 (October 2007): 373-98.

I4I. "Q\&A with Alan Dershowitz," Jerusalem Post, October 20, 2005; Walzer, "Israel Must Defeat Hamas." See also Pascal Vennesson, "War under Transnational Surveillance: Framing Ambiguity and the Politics of Shame," Review of International Studies 40, no. I (January 20I4): $25-5$ I.

I42. Michael N. Schmitt, "Human Shields in International Humanitarian Law," Israel Yearbook on Human Rights 38 (2008): 17-59; Rewi Lyall, "Voluntary Human Shields, Direct Participation in Hostilities, and the International Humanitarian Obligation of States," Melbourne Journal of International Law 9, no. 2 (2008): I-2I.

I43. Dinstein, The Conduct of Hostilities under the Law of International Armed Conflict, I2I-3I.

I44. Paul W. Kahn, "What Gaza and Ukraine Have in Common," Al Jazeera America, July I9, 20I4, accessed July 20, 20I4, http://america.aljazeera.com/opinions/20I4/7/gaza-ukraine -internationallawwarcivilians.html. Contrast this analysis with Adam Roberts, "The Palestinians, the Uprising and International Law," Journal of Refugee Studies 2, no. I (1989): 26-39, and Yishai Schwartz, "Israel's Deadly Invasion of Gaza Is Justified," New Republic, July 2I, 20I4. A subtle discussion is Jeffrey McMahan, “Gaza: Is Israel Fighting a Just War?,” Prospect Magazine, August 5, 20I4, accessed November 23, 20I4, http://www.prospectmagazine.co.uk/philosophy/gaza-is -israel-and-hamass-conflict-a-just-war.

I45. "Hamas Declares Support for Palestinian Bid to Join International Criminal Court," Guardian, August 23, 20I4. Ironically, now the United States pressures the PA not to proceed down this path, lest it lead to war crimes proceedings against Israel.

I46. Adnan Abu Amer, "Hamas Eyes Armed Resistance from West Bank," Al-Monitor, September 9, 20I4; Tareq Baconi, "Why Now is the Time to Talk to Hamas," The Guardian, May 2, 2017.

I47. Cf. Alon Confino, "Miracles and Snow in Palestine and Israel: Tantura, a History of 1948," Israeli Studies I7, no. 2 (Summer 2012): 25-6I.

I48. Bradley Simpson, "The Biafran Secession and the Limits of Self-Determination," Journal of Genocide Research I6, nos. 2-3 (June-September 20I4): 377-54. India was a major, if isolated supporter of the secession. Sonia Cordera, "India's Response to the 1971 East Pakistan Crisis: Hidden and Open Reasons for a Humanitarian Intervention," Journal of Genocide Research 17, no. I (2015): 45-62.

I49. Asli Aydintasbas interview with Khaled Meshaal; Nathan Thrall, "Hamas's Chances," London Review of Books, August 2I, 2014.

I50. Iris Marion Young, "Self-Determination as Non-Domination: Ideals Applied to Palestine/Israel," Ethnicities 5, no. 2 (June 2005): 139-59.

I5I. PASSIA, Bulletin on Gaza (June 2008). These statistics are based on 2007 estimates: 
accessed November I, 2009, http://www.passia.org/publications/bulletins/gaza/pdf/GAZA\% 20I.pdf.

152. "In all, some 200,000 refugees came to Gaza, whose original inhabitants numbered only 80,000": accessed November I, 2009, http://www.un.org/unrwa/refugees/gaza.html.

153. "Demolition and Eviction of Bedouin Citizens of Israel in the Naqab (Negev)—The Prawer Plan," Adalah: Legal Center for Arab Minority Rights in Israel, accessed September I, 20I4, http://adalah.org/eng/Articles/1589/Demolition-and-Eviction-of-Bedouin-Citizens-of-in-; Negev Coexistence Forum for Civil Equality, accessesd September I, 20I4, http://www.dukium.org/eng/.

I54. Patrick Wolfe, "Settler Colonialism and the Elimination of the Native," Journal of Genocide Research 8, no. 4 (2006): 387-410.

155. Graham Usher interview with Yasser Arafat, "Not Red Indians," Al-Ahram, November 4-IO, 2004, accessed September I, 2009, http://weekly.ahram.org.eg/2004/715/reI7.htm; cf. Karma Nabulsi, "Out of the Carnage of Gaza a New Spirit: We Are All Palestinians," Guardian, August I2, 2014 .

156. See Benny Morris and Ari Shavit, "Survival of the Fittest," Ha'aretz, January 9, 2004.

I57. I leave to one side the legal issues surrounding the UN Charter's conferral of the right to self-defense against other states, as distinct from IHL's license for states to engage in security actions against a people it is occupying.

158. Richard Falk, "Some Legal Reflections on Prolonged Israeli Occupation of Gaza and the West Bank," Journal of Refugee Studies 2, no. I (1989): 45-46.

159. Lemkin, Axis Rule in Occupied Europe, 92.

I6o. Ibid.

I6r. Ibid., 79 .

162. Alexa Stiller, "Semantics of Extermination: The Use of the New Term Genocide in the Nuremberg Trials and the Genesis of a Master Narrative," in Reassessing the Nuremberg Military Trials, ed. Kim C. Priemel and Alexa Stiller (New York: Berghahn Books, 20I2), I04-34.

163. For this vocabulary, see Balakrishnan Rajagopal, "Counter-Hegemonic International Law: Rethinking Human Rights and Development as a Third World Strategy," Third World Quarterly 27, no. 5 (July 2006): 767-83.

164. Lemkin, Axis Rule in Occupied Europe, 94-95.

I65. ICRC, Israel, and the Occupied Territories, accessed September 2, 20I4, http:// www.icrc.org/eng/where-we-work/middle-east/israel-occupied-territories/; http://www.icrc.org/ eng/assets/files/annual-report/current/icrc-annual-report-israel.pdf; also see the UN Office for the Coordination of Humanitarian Affairs (OCHA) work in Palestinian Territories, accessed September 2, 20I4, http://www.ochaopt.org/content.aspx?id = I0I0055. 